\title{
South Korea's president-elect promises science boost
}

\section{Park Geun-hye vows to raise investment in basic research and to accelerate Moon-lander plans.}

\section{Soo Bin Park}

\section{December 2012}

South Korea's thriving research base could be propelled to new heights if its next president makes good on her election promises. Park Geun-hye narrowly defeated her rival, Moon Jae-in, in the presidential election on 19 December, and will become the country's first female president when she takes office on 25 February.

Sixty-year-old Park, who studied electronic engineering at Sogang University in Seoul, pledged during her campaign that science and technology policy would become the cornerstone of her government's work. Park's conservative Saenuri Party, which forms South Korea's current government under President Lee Myungbak, plans to increase the total expenditure on research and development to $5 \%$ of the gross domestic product by 2017 , up from $4 \%$ in 2011 . The government's investment in basic science will rise from $35.2 \%$ of that total to $40 \%$ by 2017 , Park said. She also aims to set up a new overarching 'ministry of future innovative

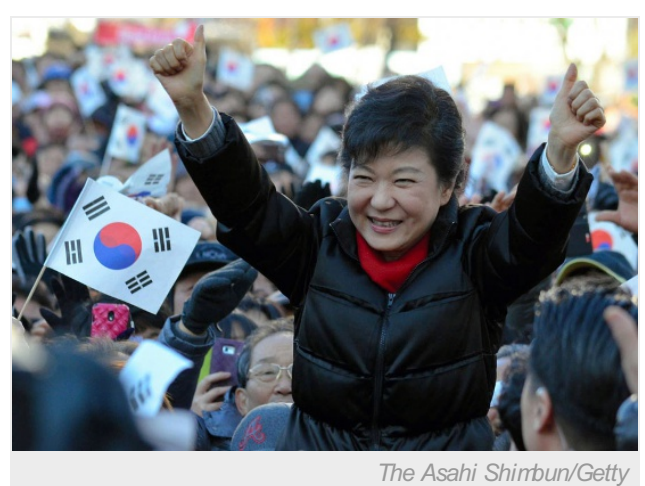

South Korean President-elect Park Geun-Hye on the campiagn trail. science', which would be separate from the current Ministry of Education, Science and Technology.

Dongil Kwon, a materials engineer at Seoul National University who helped to draft Park's election pledges, says that the new ministry would have an unprecedented role. "It is strategically crucial for the president to take care of science and technology across the various ministries, not only through the science and technology ministry," he says. "The new ministry would give an opportunity to intercross between science and other fields such as agriculture, national defence, informational technology, medicine and even art."

Dae Kyong Kim, a pharmacist at Chung-Ang University who also worked on Park's campaign promises, thinks that her victory is a positive sign for the biotechnology industry. "Biotechnology consumes so much time and money, but until now the support was insufficient and the investment was sporadically given." He is optimistic that "the new government will strengthen the country's competitiveness".

\section{Stability for scientists}

One of Park's main campaign pledges was to provide better welfare and a stable environment for scientists — by providing more support to female scientists who want to take career breaks to have children, for example - and to cut the unemployment rate among researchers.

During the final campaign debate, Park also flagged the aerospace industry as an important yardstick of national power. North Korea's successful long-range rocket launch this month and South Korea's recent failures to loft a satellite of its own in to orbit are raising tensions in the region. "Now is the moment to add momentum to the peaceful use of space," Park said. She promised to pull forward plans to send a landing module to the Moon from 2025 to 2020, and to develop a domestic satellite launcher to substitute the current Naro-1 rocket by 2021.

Park is also a keen supporter of nuclear energy, which provides roughly $30 \%$ of the country's electricity. Park agreed with her presidential rival that it was important to develop the country's renewable-energy capacity, but that it could not be the sole source of the nation's power.

Park's plans build on the controversial legacy of her father, South Korea's longest-serving dictator, Park Chung-hee. During his 18 years of autocratic rule he was criticized for widespread human-rights abuses, but he also brought rapid industrialization to the country. He founded numerous scientific institutions, including the nation's premier research centre, the Korea Advanced Institute of Science and Technology (KAIST), and the Daedeok Science Town in Daejeon. Chung-hee also invested heavily in the country's energy infrastructure, building a rash of power plants and research centres for hydroelectric, thermoelectric, nuclear and solar energy. 
Nature | doi:10.1038/nature.2012.12114 